\title{
Sampling of an STT event over the Eastern Mediterranean region by lidar and electrochemical sonde
}

\author{
A. Papayannis ${ }^{1}$, D. Balis ${ }^{2}$, P. Zanis ${ }^{3}$, E. Galani ${ }^{2}$, H. Wernli ${ }^{4}$, C. Zerefos ${ }^{5}$, A. Stohl ${ }^{6}$, S. Eckhardt ${ }^{6}$, and V. Amiridis ${ }^{2}$ \\ ${ }^{1}$ Department of Physics, National Technical University of Athens, Zografou, Greece \\ ${ }^{2}$ Laboratory of Atmospheric Physics, Aristotle University of Thessaloniki, Thessaloniki, Greece \\ ${ }^{3}$ Research Center for Atmospheric Physics and Climatology, Academy of Athens, Athens, Greece \\ ${ }^{4}$ Institute of Atmospheric Physics, University of Mainz, Mainz, Germany \\ ${ }^{5}$ Laboratory of Climatology, Geology Department, University of Athens, Athens, Greece \\ ${ }^{6}$ Norsk Institutt for Luftforskning (NILU), P.O. Box 100, 2027 Kjeller, Norway
}

Received: 5 January 2005 - Revised: 13 April 2005 - Accepted: 8 June 2005 - Published: 15 September 2005

\begin{abstract}
A two-wavelength ultraviolet (289-316 nm) ozone Differential Absorption Lidar (DIAL) system is used to perform ozone measurements in the free troposphere in the Eastern Mediterranean (Northern Greece). The ozone DIAL profiles obtained during a Stratosphere-toTroposphere Transport (STT) event are compared to that acquired by an electrochemical ozonesonde, in the altitude range between 2 and $10 \mathrm{~km}$. The measurement accuracy of these two instruments is also discussed. The mean difference between the ozone profiles obtained by the two techniques is of the order of $1.11 \mathrm{ppbv}(1.86 \%)$, while the corresponding standard deviation is $4.69 \mathrm{ppbv}(8.16 \%)$. A case study of an STT event which occurred on 29 November 2000 is presented and analyzed, using ozone lidar, satellite and meteorological data, as well as air mass back-trajectory analysis. During this STT event ozone mixing ratios of 55-65 ppbv were observed between 5 and $7 \mathrm{~km}$ height above sea level (a.s.1.). Stratospheric air was mixed with tropospheric air masses, leading to potential vorticity $(P V)$ losses due to diabatic processes. The ozone DIAL system can be used for following STT events and small-scale mixing phenomena in the free troposphere, and for providing sequences of vertical ozone profiles in the free troposphere.
\end{abstract}

Keywords. Atmospheric composition and structure (Evolution of the atmosphere; Instruments and techniques) - Meteorology and atmospheric dynamics (Middle atmosphere dynamics; Turbulence)

\section{Introduction}

Ozone plays a significant role in the gas-phase chemistry of the troposphere as an important oxidant and as a major precursor of the hydroxyl $(\mathrm{OH})$ radicals, which in turn act

Correspondence to: A. Papayannis

(apdlidar@central.ntua.gr) as removal agents, through oxidation, for a large number of trace gases in the troposphere. In addition, ozone influences the radiative balance of the troposphere, since it is a strong absorber in the infrared and the ultraviolet part of the spectrum (Roelofs et al., 1997). The recent increase in the tropospheric ozone concentration, at both of the Earth's hemispheres, is of major concern to the scientific community worldwide (Bojkov, 1986; Logan, 1994; De Muer et al., 1995; Ancellet and Beekmann, 1997; Oltmans et al., 1998; Trickl et al., 2003; Wild et al., 2004; Lazaridis et al., 2005). Tropospheric ozone has its origin both in the stratosphere through Stratosphere-to-Troposphere Transport (STT) events and in the troposphere through photochemical processes. In the latter, ozone formation results from oxidation of carbon monoxide, nitrogen oxides and hydrocarbons (Fishman and Crutzen, 1978; Brasseur et al., 1999).

The most common occurrences of STT events in the extratropics are associated with tropopause folds (Danielsen, 1968; Davies and Schuepbach, 1994; Kentarchos et al., 2000; Kowol-Santen and Ancellet, 2000; Bertin et al., 2001; James et al., 2003). Although in principle the air remaining in the fold in the upper troposphere re-enters the lower stratosphere towards the jet exit region, the stretching of stratospheric intrusions to ever finer scales and a deep descent into the troposphere leads to irreversible transport as the stratospheric air becomes mixed with the surrounding air. Mixing has been attributed to turbulence, which can destroy the filaments physically, and to radiation, which can dissolve the $P V$ anomalies and impact the occurrence and strength of the turbulence (Forster and Wirth, 1999). Furthermore, fragmentation of the intruded filaments into a train of stalactite features is an irreversible process that isolates each feature on an isentropic surface and thereby provides the time and the surface area of the interface between the two air masses for effective subsequent mixing (Vaughan et al., 1994; Appenzeller et al., 1996). Hence, deep and intense intrusions of stratospheric air penetrating down to lower tropospheric levels or even to the 
surface are important for stratosphere-to-troposphere transport and they are more relevant than the shallow ones for atmospheric chemistry as they lead to composition changes (Stohl et al., 2003; Zanis et al., 2003). Therefore, it is of crucial importance to study the tropospheric ozone variability with increased spatial and temporal resolution over extended measuring periods.

The DIAL technique is the most versatile to monitor the tropospheric ozone vertical profile variability with high spatial $(<300 \mathrm{~m})$ and temporal $(<15 \mathrm{~min})$ resolution (Papayannis et al., 1990), thus allowing a new insight into relatively small-scale mixing phenomena associated with exchanges between the troposphere and the stratosphere (Browell et al., 1987; Ancellet et al., 1991, 1994; Beekmann et al., 1997; Ravetta and Ancellet, 2000; Vaughan et al., 2001) or between the Planetary Boundary Layer (PBL) and the adjacent free troposphere (Papayannis, 1989; Ancellet and Ravetta, 2005). Ozone vertical profile measurements in the free troposphere and the lower stratosphere using the differential absorption lidar (DIAL) technique have been performed during the last twenty years, mostly in the Northern Hemisphere, either from ground-based or airborne platforms (Pelon and Mégie, 1982; Browell et al., 1987; Papayannis, 1989; Ancellet et al., 1991; Kempfer et al., 1994; Eisele et al., 1999; Guirlet et al., 2000; Galani et al., 2003; Zanis et al., 2003; Ancellet and Ravetta, 2005). The recent use of solid-state or Raman-shifted DIAL systems offers the possibility to work on a fully operational mode, continuously, over several days (Eisele et al., 1999; Zanis et al., 2003), as well as for longterm ozone monitoring in the troposphere (Beekmann et al., 1994a).

The purpose of this paper is to present a case of sampling of an STT event and the corresponding mixing of stratospheric with tropospheric air over the Eastern Mediterranean region, by using the ozone DIAL system of the Aristotle University of Thessaloniki (AUTH) in the frame of the STACCATO project (Stohl et al., 2003). The ozone lidar profiles obtained during the STT event are compared to that acquired by an Electrochemical Concentration Cell (ECC) attached to a free-flying balloon. A major part of the accuracy assessment of the ozone DIAL measurements has been previously presented by Papayannis et al. (1990), while the accuracy of the ECC ozone measurements has already been analytically addressed by Beekmann et al. (1994b) and by Beekmann et al. (1995). Therefore, in this paper we address the measuring accuracy of both ozone profiling techniques only very briefly.

In Sect. 2, both ozone profiling measurement techniques (DIAL and ECC-sonde) are presented and a short error description is given. Section 3 presents the intercomparison results between ozone DIAL and ECC measurements. In this section the differences observed in the ozone measurements are presented and discussed with respect to the instrumental error sources. Section 4 presents a case study analysis of an STT event which occurred over Thessaloniki, Greece on 29 November 2000, during the STACCATO project. Finally, Sect. 5 presents a discussion and our concluding remarks.

\section{Instruments description and measuring accuracy}

\subsection{The UV DIAL system}

The ultraviolet DIAL system was implemented in 1999 at the Laboratory of Atmospheric Physics (LAP) of AUTH, located in Thessaloniki $\left(22.9^{\circ} \mathrm{E}, 40.5^{\circ} \mathrm{N}\right)$ and is described by Papayannis et al. (1999). The system is able to perform ozone measurements in the free troposphere $(2-12 \mathrm{~km})$ with a high temporal (20-40 $\mathrm{min})$ and spatial $(\sim 300-1000 \mathrm{~m})$ resolution, mainly during nighttime conditions. The DIAL system is based on a frequency quadrupled Nd:YAG laser $(266 \mathrm{~nm})$ and subsequent stimulated Raman shifting in a low-pressure deuterium $\left(D_{2}\right)$ cell (Ancellet et al., 1989). Thus, the emitted laser beams, at a $10 \mathrm{~Hz}$ repetition rate, have energies of $12 \mathrm{~mJ}$ and $8 \mathrm{~mJ}$ at $289 \mathrm{~nm}$ and $316 \mathrm{~nm}$, respectively. The backscattered laser radiation is collected by a $500-\mathrm{mm}$ diameter Newtonian telescope and the wavelength separation is performed by a Czerny-Turner flat grating (4960lines/mm) spectrometer. The telescope's field-of-view (1-mrad full angle) permits correct ozone profile measurements to be performed only at altitudes higher than $2 \mathrm{~km}$ a.s.l., due to the incomplete overlap of the telescope's field-of-view with the emitted laser beam.

The retrieval of the tropospheric ozone profile is based on the DIAL equation (Papayannis et al., 1990), which takes into account both statistical and systematic errors, occurring during the signal acquisition and processing. Previous studies (Papayannis et al., 1990; Beekmann et al., 1994b) have analytically presented these two error sources, as well as the relevant instrumental errors. These errors typically include the electronic noise of the detectors, the possible misalignment of the optical system, the temporal variability of the laser output energy and that of the atmospheric optical thickness. Based on this analysis and using a similar DIAL system design and after data averaging and filtering (in order to increase the signal-to-noise (SNR) ratio to higher than 3), the estimated ozone-DIAL measurement precision is of the order of $5 \%$ at $6 \mathrm{~km}$ and of the order of $10 \%$ at $12 \mathrm{~km}$ for a typical integration time of $1 \mathrm{~h}$. The lidar data set was smoothed using a running least-squares fit to a second-order polynomial, thus the resulting spatial resolution on the retrieved ozone profile was kept close to $150 \mathrm{~m}$ at $3 \mathrm{~km}$ height, to $300 \mathrm{~m}$ at $6 \mathrm{~km}$ height and to $1000 \mathrm{~m}$ at $12 \mathrm{~km}$ height.

\subsection{ECC-sonde}

In this ECC-sonde DIAL intercomparison, which is a common practice during the last ten years (Ancellet et al., 1989; Beekmann et al., 1994b; Kempfer et al., 1994; Beekmann et al., 1995; Grabbe et al., 1996; Eisele et al., 1999; Vaughan et al., 2001; Ancellet and Ravetta, 2003), a Vaisala ECC5A ozonesonde was used to measure the vertical profile of ozone in the troposphere. The ECC-sonde was flown together with a radiosonde (RS80-Vaisala, Finland) used for the measurements of the vertical profile of the main meteorological parameters (pressure, temperature and relative humidity). The 

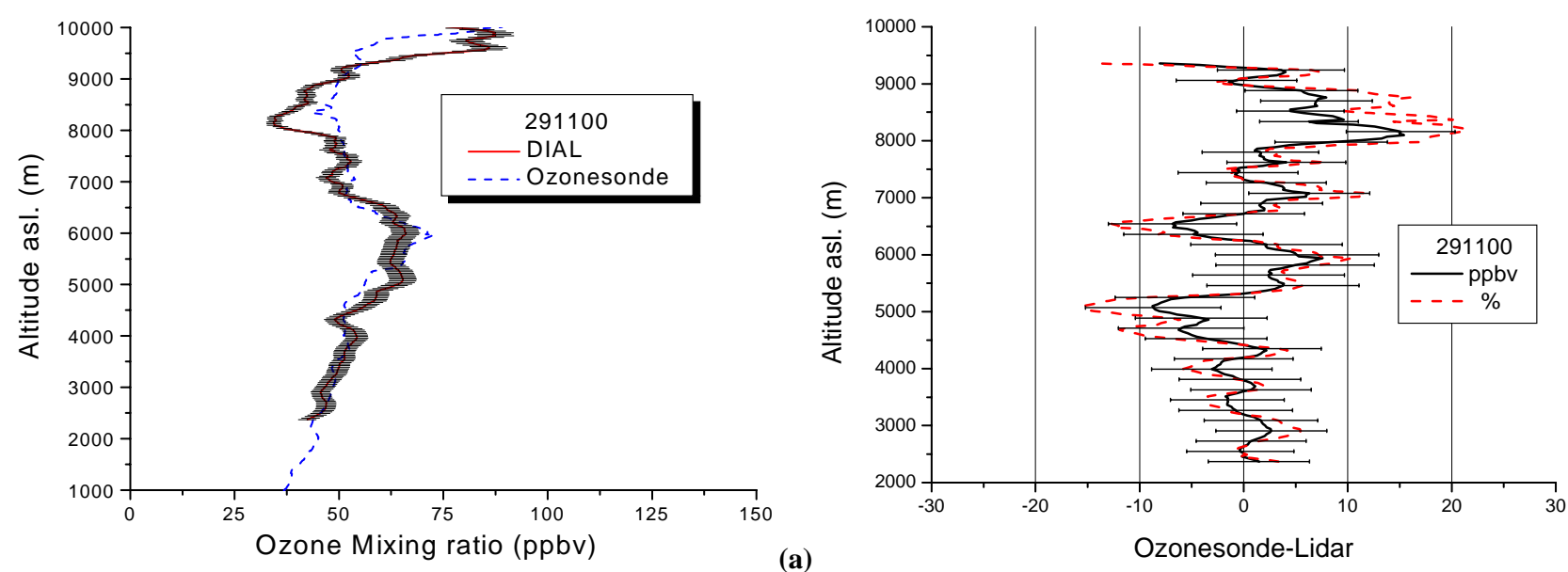

(b)

Fig. 1. (a) Ozone vertical profile measured by the AUTH DIAL system (solid line) and by the ECC-sonde (dashed line) on 29 November 2000 at 18:00 UT over Thessaloniki. (b) The relative difference between the ozone profiles derived from ozonesonde and lidar, as a function of altitude (in ppbv and \%) on 29 November 2000 at 18:00 UT over Thessaloniki.

RS80-15 radiosonde was flown by the Hellenic National Meteorological Service (HNMS) at the "Makedonia" Airport, located $15 \mathrm{~km}$ away from the lidar site. Prior to flight the ECC-sonde was thoroughly tested and calibrated according to the procedure described by Komhyr (1986). Following the SPARC review (WMO, 1998) the whole ECC-sonde ozone profile (both stratospheric and tropospheric one) was normalized by the total ozone column value measured by a Brewer spectrophotometer located at the AUTH lidar station. This normalization (or correction) factor, given as the ratio of the total ozone value derived by the Brewer instrument to that measured by the ozonesonde, was found equal to 1.02. This correction factor (CF) is normally used as a quality criterion of the ECC sonde data and may range from 0.9 up to 1.15 (Logan et al., 1994, 2001). If the CF value differs from unity (e.g. by more than 5\%), its application may be not appropriate for the tropospheric part of the profile and may distort its shape. Therefore, the $\mathrm{CF}$ has to be applied to the whole ozone profile and after all altitude-dependent corrections have been applied (WMO, 1998). In order to derive the sonde total ozone value, one needs to estimate the residual ozone column above the bursting point of the sonde. This is achieved by fitting a mid-latitude standard ozone profile (U.S. Atmosphere, 1976) to the ozone concentration value measured at the maximum reached altitude (Beekmann et al., 1994b).

Another important error in ECC-sondes measurements is the error related to the altitude restitution. The response time of the ECC-sonde is reported to be 20-30 s (Komhyr, 1969), which means that for a typical ascent velocity of $5 \mathrm{~m} / \mathrm{s}$, the effect of the response time is equivalent to a mean altitude shift of about $125 \mathrm{~m}$. Following Beekmann et al. (1994b) and considering a positive gradient of ozone of $0.08 \times 10^{12} \mathrm{~mol} . \mathrm{cm}^{-3} \mathrm{~km}^{-1}$ and a mean ozone concentration of $0.8 \times 10^{12} \mathrm{~mol} . \mathrm{cm}^{-3}$ (e.g. in the altitude region
3-6 km a.s.1.), then an altitude shift of $125 \mathrm{~m}$ yields an $\sim 1 \%$ ozone underestimation. In the contrary, considering a negative gradient of ozone of $-0.03 \times 10^{12} \mathrm{~mol} . \mathrm{cm}^{-3} \mathrm{~km}^{-1}$ and a mean ozone concentration of $0.9 \times 10^{12} \mathrm{~mol} . \mathrm{cm}^{-3}$ (e.g. in the altitude region $6-9 \mathrm{~km}$ a.s.1.), then an altitude shift of $125 \mathrm{~m}$ yields an $\sim 0.4 \%$ ozone overestimation. Errors related to the preparation of sondes and errors occurring during the flight induce an additional systematic error, thus allowing the precision of ozone measurements by the ECCsondes to be of the order of $\pm 3 \%$ up to the upper troposphere (Beekmann et al., 1994b). Also taking into account the error arising from the incorrect estimation of the background current of the ECC-sonde in the troposphere (up to 6-7\% at $400 \mathrm{hPa}$ ) an overall precision of the order of $10 \%$ has been finally attributed to the ECC-sonde measurement throughout the whole troposphere (Beekmann et al., 1995; Komhyr et al., 1995).

\section{Ozone profiles intercomparison}

The ozone profiles' intercomparison between the ECC-sonde and the DIAL system took place on the evening (18:00 UT) of 29 November 2000 over the city of Thessaloniki, Greece. Averaging time of the lidar profile was of the order of $60 \mathrm{~min}$ (corresponding to 36000 laser shots), the last $50 \mathrm{~min}$ of which coincided with the ECC-sonde measurements. The spatial resolution of the retrieved lidar ozone profile was kept close to $150 \mathrm{~m}$ at $3 \mathrm{~km}$ height, to $300 \mathrm{~m}$ at $6 \mathrm{~km}$ height and to $1000 \mathrm{~m}$ at $12 \mathrm{~km}$ height. The maximum height reached by the lidar was $10 \mathrm{~km}$. The ozone profile intercomparison is given in Fig. 1a, where the ozone mixing ratio is expressed in ppbv, as a function of the geometric altitude a.s.l. which is given in $\mathrm{m}$. The error bars on the lidar ozone profile, taking into account both statistical and systematic errors, are also shown (they refer to a confidence level of $68 \%(1 \sigma)$ ). The 
estimated precision of the ECC-sonde data is of the order of $10 \%$ throughout the whole troposphere.

The relative difference between the ozone profiles derived from the ozonesonde and the lidar, as a function of altitude, expressed in ppbv and in \%, is presented in Fig. 1b. The error bars (at a confidence level of 68\% $(1 \sigma)$ ) on the relative difference ozone profile in ppbv are also shown.

The general agreement between both ozone profiles is generally quite good, as the relative difference between the ozone profiles generally stays within the $\pm 20 \%$ limit from $2 \mathrm{~km}$ up to $10 \mathrm{~km}$ height. The mean difference between the ozone profiles obtained by the two techniques is of the order of $1.11 \mathrm{ppbv}(1.86 \%)$, while the corresponding standard deviation is $4.69 \mathrm{ppbv}(8.16 \%)$, indicating that there is no systematic bias for the lidar system. The largest differences (from 8 to $15 \mathrm{ppbv}$ or from -15 to $20 \%$ ) occur around $5 \mathrm{~km}, 6.6 \mathrm{~km}$, $8.2 \mathrm{~km}$ and $9.5 \mathrm{~km}$ height, which may be explained by: i) the lower vertical resolution of the lidar system compared to the higher one of the ECC-sonde (Komhyr, 1969) (e.g. at $6 \mathrm{~km}$ the height resolution of the lidar data is $300 \mathrm{~m}$ and that of the sonde data is of the order of $100 \mathrm{~m}$ ), as was previously discussed, ii) the fact that the two instruments probe different air masses, and iii) the different way in which the lidar and ECC-sondes probe the atmosphere (the lidar profile is a time average of instantaneously measured vertical profiles over $1 \mathrm{~h}$ and the sonde profile is a sequence of single data points).

The sonde data (Fig. 1a) also show a small sharp peak of $70 \mathrm{ppbv}$, around $6 \mathrm{~km}$ height and a minimum of $45 \mathrm{ppbv}$ around $8.5 \mathrm{~km}$ height, while the lidar profile shows a much broader maximum (minimum) between $4.5 \mathrm{~km}$ and $6.8 \mathrm{~km}$ (between $8 \mathrm{~km}$ and $9 \mathrm{~km}$ ). As it is shown in the next section, the ozone peak around $6 \mathrm{~km}$ height is related to an STT event. We also have to mention that concurrent aerosol lidar measurements at $355 \mathrm{~nm}$ performed over Thessaloniki did not show significant aerosol loads over $3 \mathrm{~km}$ height, thus no aerosol correction was applied to the retrieved ozone DIAL profiles (Papayannis, 1989).

As previously discussed, structures of the ozone vertical profile are quite well reproduced by the lidar technique. However, we have to note that the ozone profile measured by the lidar does not fully resolve all fine structures, which are visible in the ECC-sonde derived profile. This may be explained, as discussed earlier, by the higher spatial resolution of the ECC-sonde measurements compared to that of the lidar measurement, as well as by the possibility that the two instruments did not sample the same air masses, since the ECC-sonde was launched some $15 \mathrm{~km}$ away from the lidar site. If we take into consideration the measuring accuracy (error bars), as well as the range resolution of both techniques, we may conclude that the general agreement between the two techniques remains quite good up to the altitude of $10 \mathrm{~km}$ height. Therefore, as a conclusion, the intercomparison of the two techniques was proven to be quite successful.

\section{Case study analysis of an STT event}

Intrusion of stratospheric air into the troposphere occurs during tropopause folding events and is associated with upperlevel frontogenesis in the upper polar (and to a lesser extent in the arctic and in the sub-tropical) jet stream region and with rapid surface cyclogenesis (Reed, 1955; Danielsen, 1968). On the other hand, cutoff lows (COL) (i.e. isolated regions of closed geopotential contours in the upper-level flow), which are also responsible for STT events, usually form when an upper air trough extends equatorwards far enough, so that a closed cyclonic circulation forms at its tip. COLs are often associated with blocked patterns (Hoskins et al., 1985; Kentarchos et al., 1998). In order to decide whether a case study represents an STT event or not, specific criteria have to be applied. These criteria are based on the fact that stratospheric air has certain characteristics, which can be used for its detection in the troposphere.

For instance, stratospheric air is characterized by high potential vorticity $(P V)$ values $\left(1 P V \mathrm{u}=10^{-6} \mathrm{~K} \mathrm{~m}^{2} \mathrm{~kg}^{-1} \mathrm{~s}^{-1}\right)$. Tropopause threshold values reported in the literature range from $1 P V u$ (Danielsen, 1968) to $3.5 P V \mathrm{u}$ (Hoerling et al., 1991), since they are also dependent on the geographical location of the sampling. A threshold value of $1.5 P V \mathrm{u}$ is often used (e.g. Shapiro, 1980; WMO, 1986) to distinguish stratospheric from tropospheric air masses. In the absence of frictional and/or diabatic effects, $P V$ is well conserved by individual air parcels and therefore can be used as a dynamical stratospheric tracer (Davies and Schuepbach, 1994). However, tropopause folds are known to be likely regions for the occurrence of turbulence and/or diabatic processes that lead to non-conservation of $P V$. Therefore, $P V$ values within the remnants of a tropopause fold ranging from about 0.5 to $1.5 \mathrm{PVu}$, are indicative of recent (within a few days) mixing of stratospheric and tropospheric air or other diabatic effects, such as radiative erosion of $P V$.

Within a stratospheric intrusion, dry air penetrates into the troposphere and hence water vapor (relative or specific humidity) may also be used as a stratospheric tracer (Appenzeller and Davies, 1992; Gray et al., 1994). In our case study analysis we use the $P V$ and the relative humidity $(\mathrm{RH})$ fields, although the latter under certain circumstances may only be an indicator of stratospheric air entering the upper troposphere. The $P V$ maps are presented on the $315 \mathrm{~K}$ isentropic surface to indicate the extent of streamers over the E. Mediterranean region. Our case study analysis also makes use of total ozone data derived by the High Resolution Infrared Radiation Sounder (HIRS), which is one of the three instruments forming NOAA's TIROS Operational Vertical Sounder (TOVS). Vertical cross sections of $P V$, RH and potential temperature (south-north and east-west direction) over Thessaloniki, provided by the European Center for Medium-Range Weather Forecasts (ECMWF), are also used to characterize the vertical extent of the STT over the lidar site. Finally, a 3-D air mass back trajectory analysis, using the trajectory model FLEXTRA (Stohl et al., 1995) based on ECMWF data analyses, is presented to indicate the 


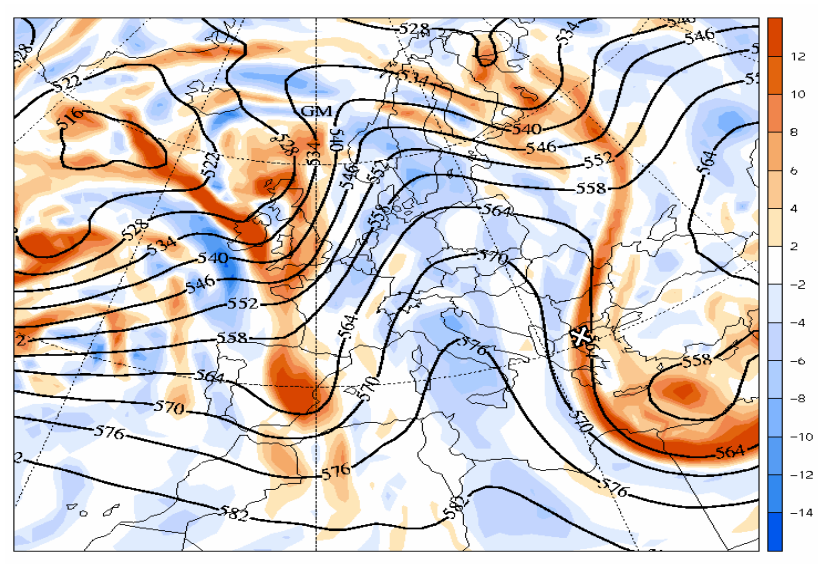

Fig. 2. The ECMWF 500-hPa geopotential height chart (black lines) over Europe on 29 November 2000 at 18:00 UT (Thessaloniki is marked by $\mathrm{X}$ ). The colour contours correspond to the relative vorticity fields (in $10^{-5} \mathrm{~s}^{-1}$ ).

origin of the air masses probed by the lidar. The spatial step is $100 \mathrm{hPa}$, from 200 to $800 \mathrm{hPa}$ height region, and the corresponding time step is 6 hours (Stohl, 1998; Stohl et al., 1998). In the following paragraph we describe an STT event which occurred over Thessaloniki on 29 November 2000.

\subsection{Case study of 29 November 2000}

On 29 November 2000 a low center was located over Siberia with a trough extending southwards towards the E. Mediterranean region (Thessaloniki is marked by $\mathrm{X}$ ), as is shown in the 500-hPa geopotential height chart (black lines) provided by ECMWF on 18:00 UT (Fig. 2). The colour contours correspond to the relative vorticity fields (in $10^{-5} \mathrm{~s}^{-1}$ ). In this figure Thessaloniki is shown to have high relative vorticity values of the order of $10-11 \times 10^{-5} \mathrm{~s}^{-1}$. This chart, together with the potential vorticity map on the $315 \mathrm{~K}$ isentropic surface on 29 November at 18:00 UT (Fig. 3), show that Thessaloniki (marked by X) was located on the western flank of a developing COL system. On the cyclonic edge of the jet (the jet stream position is marked on Fig. 2 by the red-shaded area over the E. Mediterranean area and Egypt) the isentropic $P V$ chart shows strong gradients $(\sim 3 P V \mathrm{u} / 200 \mathrm{~km})$, which correspond to the position of the frontal zone (Kayser and Shapiro, 1986). On Fig. 3 two large streamers (elongated structures generated by the southward extension and thinning of the trough) of stratospheric air being drawn isentropically equatorward, away from the polar region, are visible. The left-hand side streamer extends southwards over the Iberian Peninsula. The second streamer (eastern one) had passed over central Europe on 26 November and during that process it developed a wave-like feature. Passing over the E. Mediterranean region this streamer tends to roll up into small vorticies (with substantial thinning) away from the polar jet stream and leads to the formation of a COL event of high $P V$ values (3-5 $P V \mathrm{u}$ on the $315 \mathrm{~K}$ isentropic surface), on 30 November 2000.

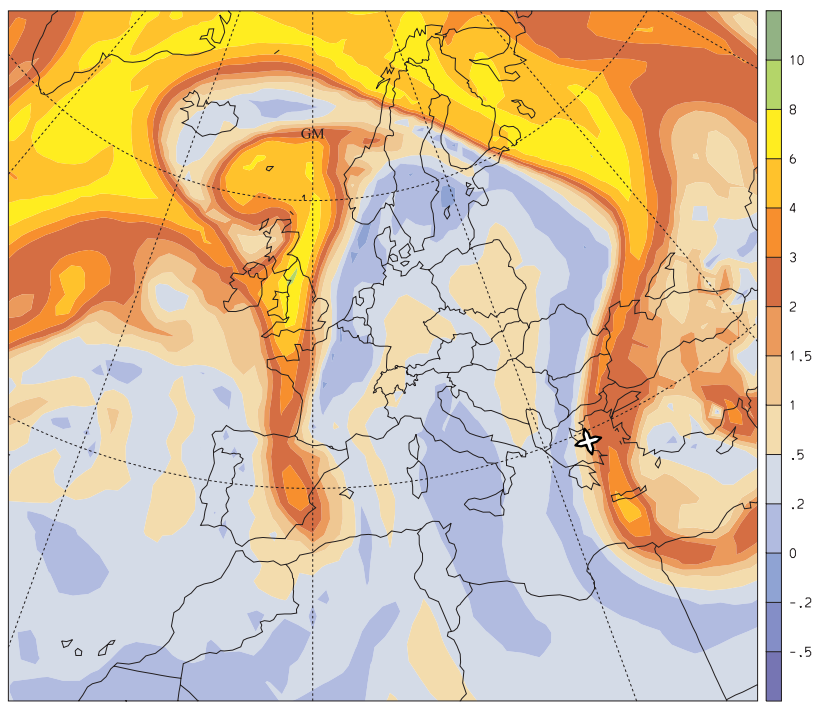

Fig. 3. Potential vorticity map in $P V$ units on the $315 \mathrm{~K}$ isentropic surface on 29 November 2000 at 18:00 UT (Thessaloniki is marked by X).

The corresponding infrared image (not shown) from the Advanced Very High Resolution Radiometer (AVHRR), from NOAA-14 satellite, taken on 29 November at 14:20 UT, clearly shows a curved band of dry air extending down to the E. Mediterranean region, indicating the dynamic evolution of the flow. The daily mean values of the specific humidity at $500-\mathrm{hPa}$ pressure levels (not shown), given by the NOAA-CIRES Climate Diagnostic Center, reveal again the presence of very dry air masses $\left(2 \times 10^{-4} \mathrm{~g} / \mathrm{kg}\right)$ extending from Bulgaria down to Libya, which correlate well with the dry air masses observed on the AVHRR image. The pattern of these dry air masses correlates again very well with the corresponding $P V$ pattern at $315 \mathrm{~K}$ isentropic surface shown in Fig. 3. The formation of the two streamers shown in Fig. 3, is also well depicted by the TOVS total ozone map (Fig. 4), where again the total ozone maximum over the E. Mediterranean (380 DU) coincides well with the position of the COL. The horizontal gradient of total ozone over Thessaloniki (marked by $\mathrm{X}$ ) from the total ozone map is estimated to be $60 \mathrm{DU} / 100 \mathrm{~km}$, close to the values presented by Beekmann et al. (1994a, b) in similar cases. Calculated values of $\mathrm{O}_{3} / P V$ ratios range between 38 and $45 \mathrm{ppbv} / P V \mathrm{u}$ in the upper troposphere over Greece during this STT event. These values are in good agreement with those obtained over central Europe (35-60 ppbv/PVu), as recently reported by Ancellet et al. (1994), Kentarchos et al. (1999), and by Stohl and Trickl (1999). On 30 November (Fig. 3) the elongated streamer passed over the Aegean Sea, with a total ozone increase - within two days - of $45 \mathrm{DU}(18 \%)$, to finally move $\mathrm{NE}$ on 30 November.

The UV-DIAL was operated during selected time periods on 29 November between 08:00 UT and 18:00 UT. Technical reasons (high solar background) did not allow us to take exploitable measurements between 12:00 and 16:00 UT, since 


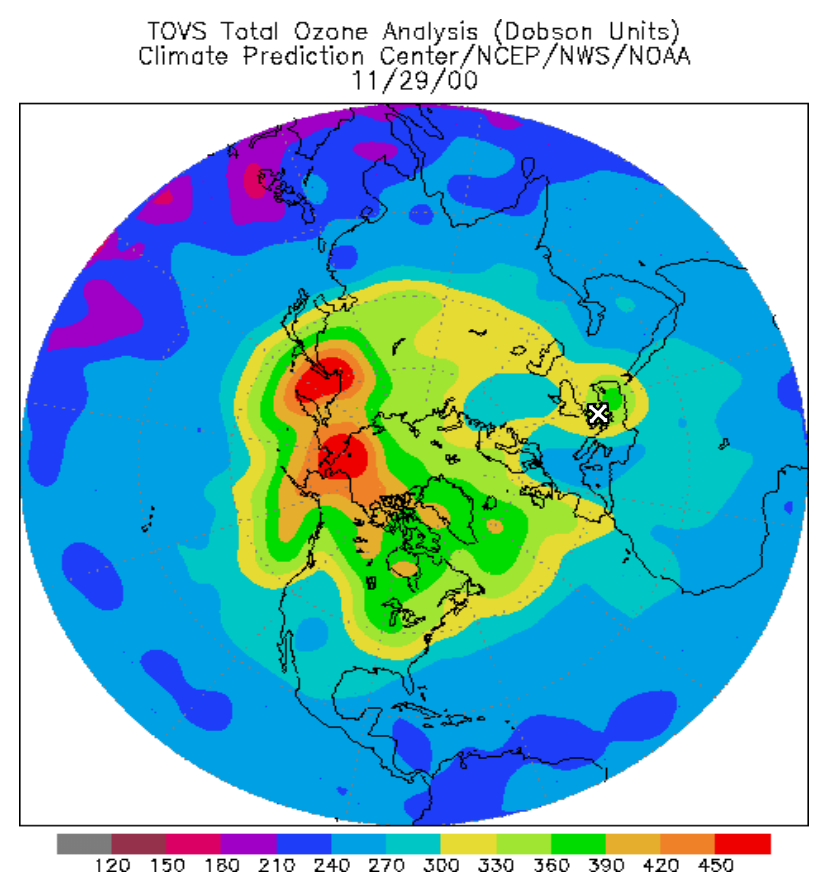

Fig. 4. The TOVS total ozone map (in DU) over Europe on 29 November 2000 at 12:00 UT (Thessaloniki is marked by X).

the maximum level height reached was of the order of $4 \mathrm{~km}$. The mean ozone DIAL profiles retrieved are presented in the altitude range between 2 and $11 \mathrm{~km}$ (Fig. 5a) and correspond to measurements averaged over $1 \mathrm{~h}$ (36000 laser shots) around 08:00 UT and over 1.5 h (54000 laser shots) around 11:00 UT and 18:00 UT, respectively. The difference between the maximum height reached during daytime (08:00 and 11:00 UT) is mainly due to the lower number of laser shots acquired around 08:00 UT than around 11:00 UT. The three ozone vertical profiles show a mean concentration of the order of 50-55 ppbv, whilst they reveal the existence of a well-defined layer of ozone rich air, between $5 \mathrm{~km}$ and $7 \mathrm{~km}$ height, with a maximum of approximately $55-65$ ppbv. The lidar profile taken around 18:00 UT and shown in Fig. 5a does not look exactly the same as the one of Fig. 1a, since, as explained, the averaging time is different, $1.5 \mathrm{~h}$ and $1 \mathrm{~h}$, respectively. The ozone vertical variability (which is of the order of $10 \mathrm{ppbv}$ ) between these 3 profiles, is observed mostly in the $2-4.5 \mathrm{~km}$ and $6-8 \mathrm{~km}$ altitude regions. This variability is frequently observed in the free troposphere and could be attributed mainly to the different origin of the sampled air masses (Papayannis, 1989; Ancellet et al., 1989; Ancellet and Ravetta, 1998).

The combined radio sounding/ozone sounding performed over Thessaloniki on 29 November 2000 at 18:00 UT (Fig. 5b) reveals the presence of dry air (relative humidity $<20 \%)$ at the same altitude region $(5-7 \mathrm{~km})$ where the ozone peak was observed. These dry ozone-rich air masses, either may be formed in the troposphere, if the polluted continental boundary layer is lifted by convection to the tropopause

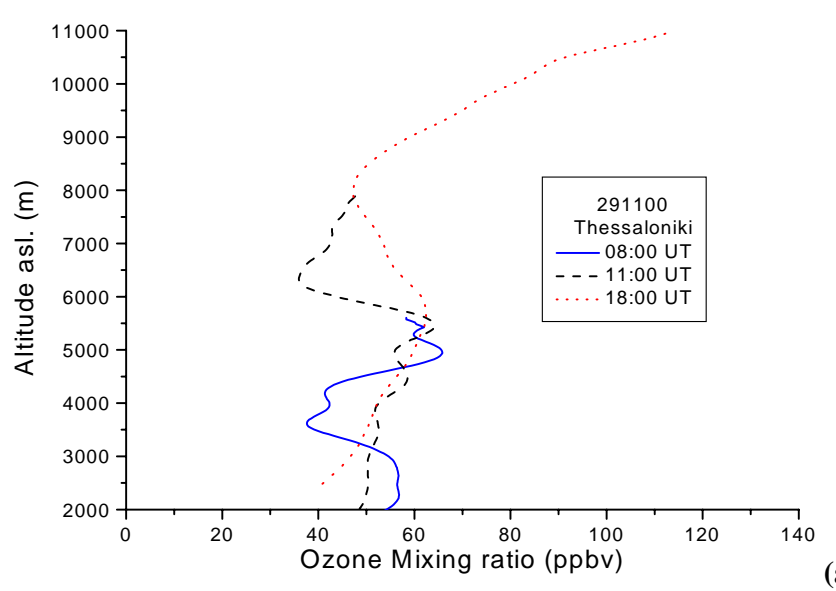

(a)

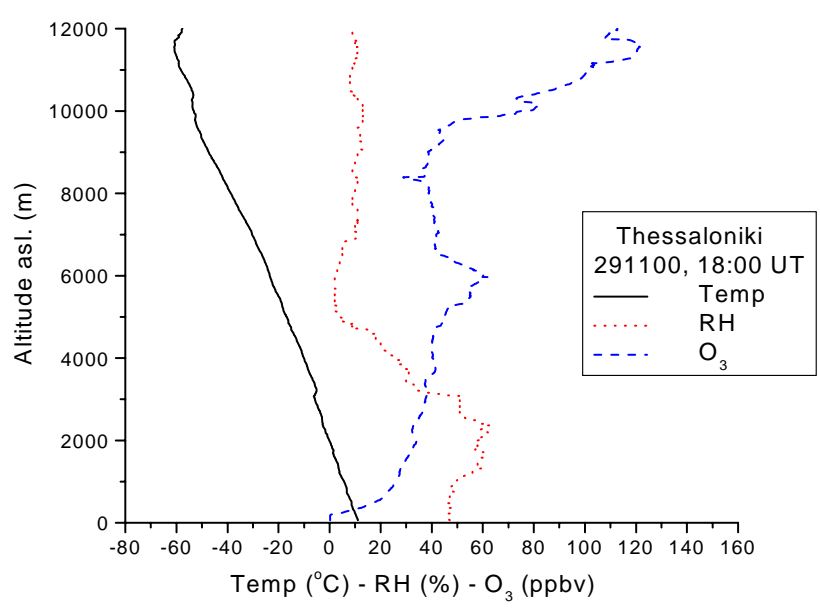

(b)

Fig. 5. (a): Ozone DIAL vertical profiles taken over Thessaloniki, on 29 November 2000 at 08:00 UT, 11:00 UT and 18:00 UT. (b): The vertical profile of the relative humidity $(\mathrm{RH}), \mathrm{O}_{3}$ and temperature obtained by a combined radiosonde/ozonesonde over Thessaloniki, on 29 November 2000 at 18:00 UT.

(Bithell et al., 2000), or have a stratospheric origin. To investigate the origin of these air masses we make use of both ECMWF analysis data and three-dimensional backward air mass trajectories. Both the lidar and the ozonesonde data reveal an increasing ozone mixing ratio (>80 ppbv) at $10 \mathrm{~km}$ height that determinines the chemical tropopause height, which is lower than the thermal tropopause height estimated from the concurrent radiosounding temperature profile to be approximately at $11.5 \mathrm{~km}$ (see Fig. 5b).

In order to examine the vertical extent of the tropopause folding within the COL we calculated the vertical cross section of the isentropic potential vorticity on 29 November at 18:00 UT (Fig. 6) passing over Thessaloniki (marked by X) by using the ECMWF analysis with a resolution of $1 \times 1$ degrees. The first cross section (Fig. 6a) corresponds to the north-south direction $\left(30^{\circ}\right.$ to $\left.50^{\circ} \mathrm{N}\right)$ and is made along the jet stream axis (downstream direction). The second cross section (Fig. 6b) corresponds to the east-west direction $\left(8^{\circ}\right.$ to $38^{\circ} \mathrm{E}$ axis), and is nearly vertical to the jet stream axis. 
Both cross sections confirm the enfolding of the tropopause (defined by the $1.5 \mathrm{PVu}$ isocontour) down to $450 \mathrm{hPa}$ on the western flank of the COL system, south of the position of Thessaloniki (Fig. 6a) and roughly down to $350 \mathrm{hPa}$, east above Thessaloniki (Fig. 6b). The bold closed contours in Figs. 6a and b, which represent the vertical cross section of the $\mathrm{RH}$ isocontour with $\mathrm{RH}=0 \%$, delineate the descending dry $(\mathrm{RH}<10 \%)$ air masses down to $750 \mathrm{hPa}$ level.

If we plot the vertical cross section of the potential temperature $(\theta)$ again along the same axes (Figs. 7a and b) we confirm again the enfolding structure of the tropopause extending again down to the $550 \mathrm{hPa}$ level on the northwestern flank of the COL (Thessaloniki is marked by $\mathrm{X}$ ). Very strong gradients of $\theta$ are observed between the 400 and $200 \mathrm{hPa}$ levels, which are typical for a tropopause folding event (Browell et al., 1987; Papayannis, 1989). Comparing Figs. 6 and 7, we can now follow exactly the enfolding structure of the tropopause progressing deeper into the lower free troposphere $(\sim 750 \mathrm{hPa}$ level$)$, as a tongue-like feature, showing strong gradients of $P V, \theta$ and $\mathrm{RH}$ values. This slopping zone has a vertical thickness of typically $1-2 \mathrm{~km}$, as also has been observed over mid-latitudes, but in much smaller longitudes $\left(2-3^{\circ} \mathrm{E}\right)$ by Ancellet et al. (1991) and Beekmann et al. (1994a). Considering a section above the position of Thessaloniki in Figs. 6a and b, it appears to be a a dry layer around the $550 \mathrm{hPa}$ level with a $P V$ value between 0.5 and $1 P V$ units and an $\mathrm{RH}$ less than $10 \%$, which coincides with the height region where the ozone maxima were observed with the lidar system and the ozonesonde (Fig. 1). This result suggests that mixing of stratospheric air with tropospheric air may have taken place in the air masses of this layer along their transport towards Thessaloniki and possible explains why the observed ozone layer of 60 ppbv between 5 and $7 \mathrm{~km}$ height is not in the order of upper tropospheric/lower stratospheric values (higher than $100 \mathrm{ppbv}$ ).

In order to investigate the origin of the rich ozone layer observed between 5 and $7 \mathrm{~km}$ height, eight-day backward trajectories using the trajectory model FLEXTRA (Stohl et al., 1995) were initialized every $250 \mathrm{~m}$. As noted by Stohl and Trickl (1999) the accuracy of the trajectories decreases with time and after 72 to $96 \mathrm{~h}$ their position (both horizontal and vertical) may be erroneous (Stohl, 1998), with typical errors being $15-20 \%$ of the transport distance. Figure 8 shows the eight-day air mass backward trajectories ending at the lidar site, between 4 and $8 \mathrm{~km}$ height, on 29 November 2000 at 18:00 UT. On the one hand, Fig. 8 indicates that there are air masses (bold trajectories) which descended from the $10 \mathrm{~km}$ height level and which had been in the lower stratosphere over Northern U.K. and Scandinavia 1-2 days before, ending between 6 and $7 \mathrm{~km}$, where the ozone maximum is observed. Two of these trajectories showed high $P V$ values $(1.5-6 P V \mathrm{u})$ and low $\mathrm{RH}(<5 \%)$ values, typical of their stratospheric origin on their way towards the observation site. $P V$ decreases along these trajectories to less than $1 P V u$ during the last two days before arrival over the observation site, indicating mixing with tropospheric air. While the mixing itself cannot be

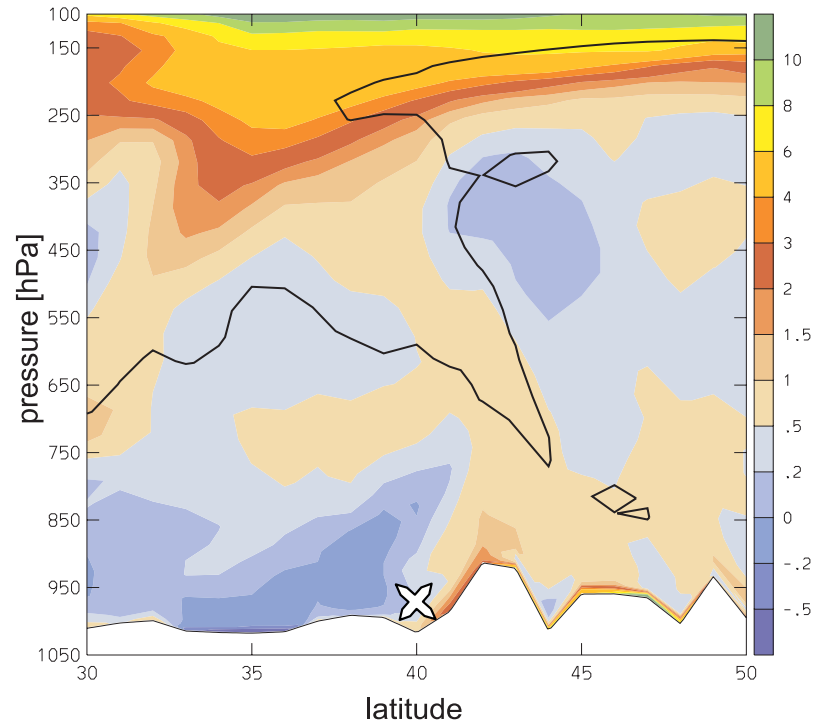

(a)

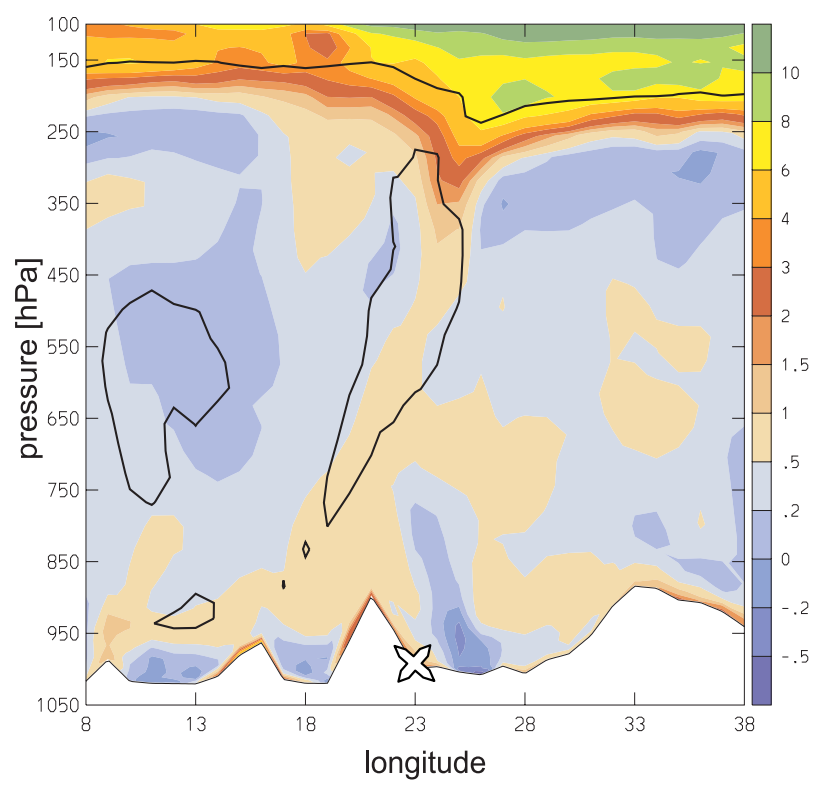

(b)

Fig. 6. (a) Vertical cross section of potential vorticity $(P V u)$ over Thessaloniki for 29 November 2000 at 18:00 UT, along the southnorth direction (latitudes form $30^{\circ}$ to $50^{\circ} \mathrm{N}$ ). Solid bold lines show regions with low humidity $(<10 \%)$ (Thessaloniki is marked by $\mathrm{X}$ ). (b) Vertical cross section of potential vorticity $(P V \mathrm{u})$ over Thessaloniki for 29 November 2000 at 18:00 UT, along the west-east direction (longitudes form $8^{\circ}$ to $38^{\circ} \mathrm{E}$ ) (Thessaloniki is marked by $\mathrm{X})$.

quantified using trajectories, the proximity to tropospheric air masses suggests such a mixing. This is in agreement with the $P V$ vertical cross sections in Figs. $6 \mathrm{a}$ and $\mathrm{b}$, where it appears as a dry layer around $550 \mathrm{hPa}$ level with a $P V$ value between 0.5 and $1 P V$ units and an $\mathrm{RH}$ less than $10 \%$, which coincides with the height region where the ozone maxima were observed. On the other hand, there is also a bundle of middle and upper tropospheric trajectories (turquoise color 


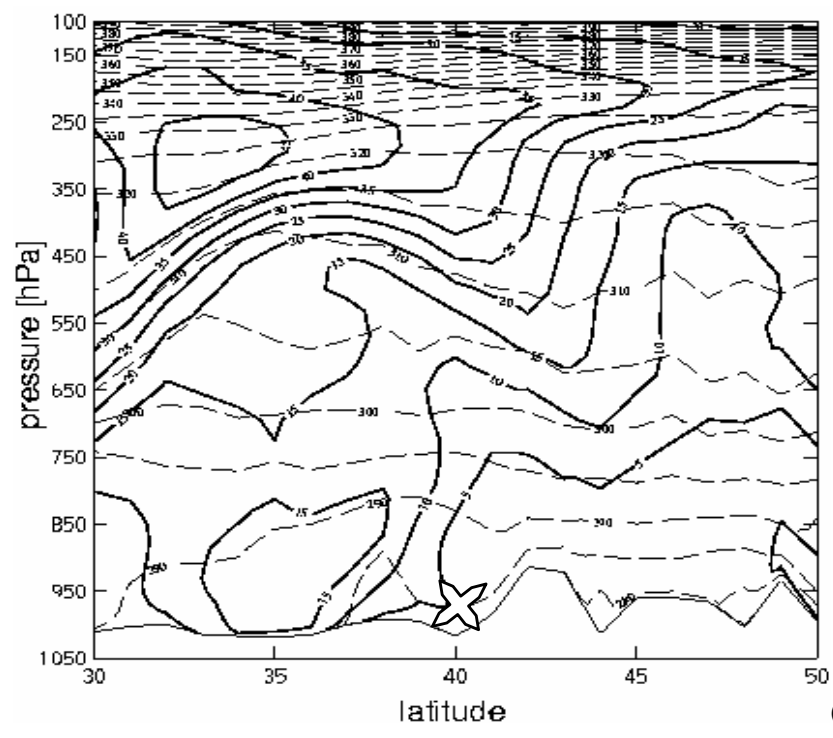

(a)

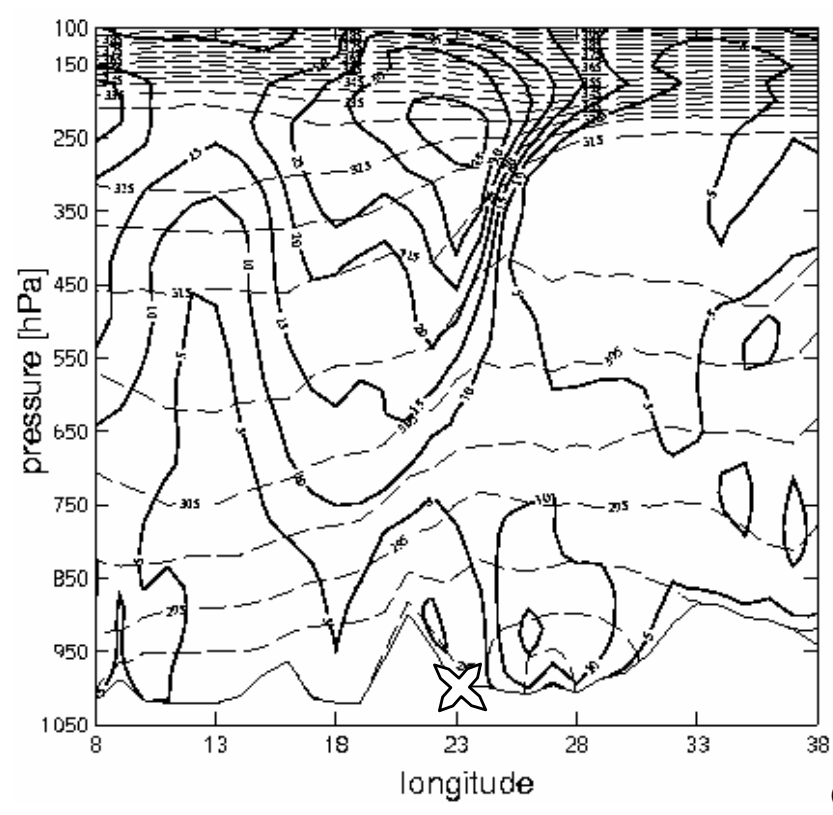

(b)

Fig. 7. (a) Vertical cross section of potential temperature (K) over Thessaloniki for 29 November 2000 at 18:00 UT, along the south-north direction (latitudes form $30^{\circ}$ to $50^{\circ} \mathrm{N}$ ) (Thessaloniki is marked by X). (b) Vertical cross section of potential temperature (K) over Thessaloniki for 29 November 2000 at 18:00 UT, along the west-east direction (longitudes form $8^{\circ}$ to $38^{\circ} \mathrm{E}$ ) (Thessaloniki is marked by $\mathrm{X}$ ).

in Fig. 8, middle) ending at similar heights with $P V$ values less than $1 P V u$ (Fig. 8, bottom), imposing the hypothesis of mixing between stratospheric and tropospheric air masses before arriving at the level where the ozone maximum is observed above the observation site. Furthermore, there is even another bundle of trajectories (brown color), which indicates clearly the strong ascent of lower tropospheric air (below $2 \mathrm{~km}$ ) to the upper troposphere $(7-8 \mathrm{~km})$ above the observation site, enforcing further the possibility of mixing between stratospheric and tropospheric air. Similar behavior showed the air mass trajectories ending over Thessaloniki, between 4 and $8 \mathrm{~km}$ height, on 29 November 2000 at 08:00 UT and 11:00 UT.

\section{Discussion and concluding remarks}

The AUTH DIAL system was used to perform ozone measurements in the free troposphere over the Eastern Mediterranean during an STT event. The DIAL profiles obtained during this event were compared to that acquired by an ECC-sonde. The intercomparison between the ozone DIAL technique and the ECC-sonde proved to be quite successful, at least under stable meteorological conditions. The ozone DIAL profile agreed quite well with that derived by the ECC-sonde in the altitude region between 2 and $10 \mathrm{~km}$, as the relative difference between these profiles generally stayed within the $\pm 20 \%$ limit. The mean difference between the ozone profiles obtained by the two techniques was of the order of $1.11 \mathrm{ppbv}(1.86 \%)$, while the corresponding standard deviation was $4.69 \mathrm{ppbv}(8.16 \%)$. The largest differences (from -8 to 15 ppbv or from -15 to $20 \%$ ) occur around $5 \mathrm{~km}, 6.6 \mathrm{~km}, 8.2 \mathrm{~km}$ and $9.5 \mathrm{~km}$ height. This may be explained by the different height resolution, the different air masses probed and the different ways the two instruments probe the atmosphere, as was previously discussed.

This intercomparison effort did not indicate any particular bias of the lidar system and is in agreement with its estimated accuracy in the upper troposphere, as well as with previously reported ozone lidar and ECC-sondes intercomparisons (Beekmann et al., 1994a, b, 1995; Grabbe et al., 1996).

Overall, it has been demonstrated that the AUTH ozone DIAL system can provide reliable measurements of the vertical distribution of ozone in the free troposphere and the lower stratosphere $(2-10 \mathrm{~km})$ with high spatial and an acceptable temporal resolution. Ozone tongues occurring during STT events, such as presented in a case study analysis in this paper, may occasionally be vertically as thick as $1-2 \mathrm{~km}$, which as shown, may be resolved and correctly reproduced by our lidar system. As a consequence, the AUTH ozone DIAL system can be used for following STT events and smallscale mixing phenomena in the free troposphere, providing sequences of vertical ozone profiles in the free troposphere (Galani et al., 2003).

The STT event of 29 November 2000 observed by lidar and ECC-sonde over Thessaloniki was characterized by the following features: a) mixing ratios of the order of 55-65 ppbv were observed in the 5-7 km altitude region, corresponding to an increase in the mean free tropospheric background ozone mixing ratios by $10-20$ ppbv (Kourtidis et al., 2002), b) the air masses probed by the lidar in the 5-7 altitude region had a stratospheric origin with $P V$ values of 1.5-6 $P V \mathrm{u}$ during their residence in the lower stratosphere. 

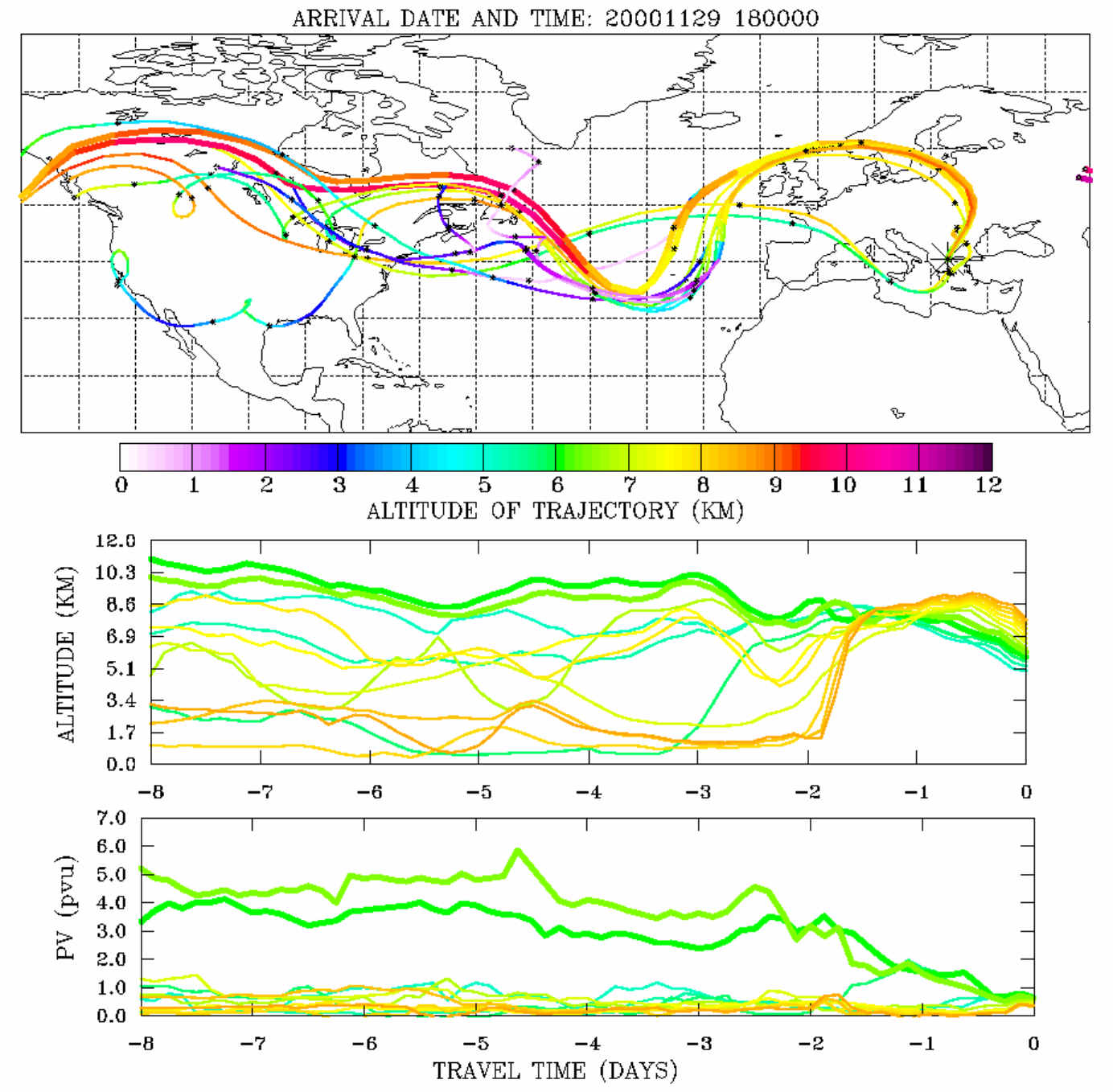

Fig. 8. Eight-day 3-D backward trajectories ending over Thessaloniki on 29 November 2000 at 18:00 UT. Top: Horizontal projection of trajectories with color-code scale according to the label bar referring to the actual heights (in km a.s.l.). Middle: Time-height profiles of the trajectories of the top plot. Bottom: $P V$ values (in $P V \mathrm{u}$ ) along the various trajectories with the color-code scale corresponding to the middle plot.

At their ending point (at $5.5 \mathrm{~km}$ height) over the lidar site, they showed $P V$ values of $0.5-1 P V \mathrm{u}$, due to mixing of stratospheric with tropospheric air, leading to $P V$ losses due to diabatic processes, c) according to the calculated RH values given by ECMWF data analyses, the stratospheric air penetrated into the lower troposphere down to the $750 \mathrm{hPa}$ level, on the north-western flank of the COL, d) below the height where the STT event took place, as studied in this paper, air with both stratospheric and tropospheric origin was detected using an eight-day backward trajectory analysis.

Acknowledgements. This study was funded by the Environment Program of the European Union under contract EVK2-CT199900050 and was conducted in the frame of the STACCATO project. This support is gratefully acknowledged. The authors would like also to thank the staff of the Hellenic National Meteorological Service of the Makedonia Airport for conducting the RS80 radiosoundings, as well as E. Kosmidis (AUTH) for the preparation and launching of the ECC-sonde. The useful comments provided by the two anonymous reviewers are greatly acknowledged. Finally, the European Center for Medium Weather Forecast (ECMWF) is acknowledged for providing the potential vorticity, relative humidity and potential temperature data. TOVS data were prepared by NCEP and downloaded from http://www.cpc.ncep.noaa.gov/ products/stratosphere/tovsto/.

Topical Editor O. Boucher thanks two referees for their help in evaluating this paper.

\section{References}

Ancellet, G., Papayannis, A., Pelon, J., and Mégie, G.: DIAL tropospheric ozone measurements using a Nd:YAG laser and the Raman shifting technique, J. Atmos. Ocean. Technol., 6, 832-839, 1989.

Ancellet, G., Pelon, J., Beekmann, M., Papayannis, A., and Mégie, G.: Ground based lidar studies of ozone exchanges between the 
stratosphere and the troposphere, J. Geophys. Res., 96, 22 40122 421, 1991.

Ancellet, G., Beekmann, M., and Papayannis, A.: Impact of a cutoff low development on downward transport of ozone in the troposphere, J. Geophys. Res., 99, 3451-3468, 1994.

Ancellet, G. and Beekmann, M.: Evidence for changes in the ozone concentration in the free troposphere over Southern Europe from 1976-1995, Atmos. Environ., 31, 2835-2851, 1997.

Ancellet, G. and Ravetta, F.: Compact airborne lidar for tropospheric ozone: description and field measurements, Appl. Opt., 37, 5509-5521, 1998.

Ancellet, G. and Ravetta, F.: On the usefulness of an airborne lidar for $\mathrm{O}_{3}$ layer analysis in the free troposphere and the planetary boundary layer, J. Environ. Monit., 5, 47-56, 2003.

Ancellet, G. and Ravetta, F.: Analysis and validation of ozone variability observed by lidar during the ESCOMPTE-2001 campaign, Atmos. Res., 74, 435-459, 2005.

Appenzeller, C. and Davies, H.: Structure of stratospheric intrusions into the troposphere, Nature, 358, 570-572, 1992.

Appenzeller, C., Davies, H. C., and Norton, W. A.: Fragmentation of stratospheric intrusions, J. Geophys. Res., 101, 1435-1456, 1996.

Austin, J. F. and Follows, M. J.: The ozone record at Payerne: an assessment of the cross tropopause flux, Atmos. Environ., 25A, 1873-1880, 1991.

Beekmann, M., Ancellet, G., and Mégie, G.: Climatology of tropospheric ozone in southern Europe and its relation to potential vorticity, J. Geophys. Res., 99, 12 841-12 853, 1994a.

Beekmann, M., Ancellet, G., Mégie, G., Smit, H., and Kley, D.: Intercomparison campaign of vertical ozone profiles including electrochemical sondes of ECC and Brewer-Mast type and a ground-based UV Differential Absorption lidar, J. Atmos. Chem., 19, 259-288, 1994b.

Beekmann, M., Ancellet, G., Martin, D., Abonnel, C., Duverneuil, G., Eideliman, F., Bessemoulin, P., Fritz, N., and Gizard, E.: Intercomparison of tropospheric ozone profiles obtained by electrochemical sondes, a ground based lidar and an airborne UVphotometer, Atmos. Environ., 29, 1027-1042, 1995.

Beekmann, M., Ancellet, G., Blonsky, S., De Muer, D., Ebel, A., Elbern, H., Hendricks, J., Kowol, J., Mancier, C., Sladkovic, R., Smit, H. G., Speth, P., and Trickl, T.: Regional and global tropopause fold occurrence and related ozone flux across the tropopause, J. Atmos. Chem., 28, 29-44, 1997.

Bertin, F., Campistron, B., Caccia, J. L., and Wilson, R.: Mixing processes in a tropopause folding observed by a network of ST radar and lidar, Ann. Geophys., 19, 1-11, 2001,

SRef-ID: 1432-0576/ag/2001-19-1.

Bithell, M., Vaughan, G., and Gray, L. J.: Persistence of stratospheric ozone layers in the troposphere, Atmos. Environ., 34, 2563-2570, 2000.

Bojkov, R. D.: Surface ozone during the second half of the nineteenth century, J. Clim. \& Appl. Meteor., 25, 343-352, 1986.

Brasseur, G., Orlando, J., and Tyndall, J. (Eds.): Atmospheric Chemistry and Global Change, Oxford University Press, 654, 1999.

Browell, E. V., Danielsen, E., Ismail, S., Gregory, G., and Beck, S. M.: Tropopause forld structrure determined by lidar and in situ measurements, J. Geophys. Res., 92, 2112-2120, 1987.

Burrows, J. P., Weber, M., Buchwitz, M., Rozanov, V., LadstädterWeissenmayer, A., Richter, A., De Beek, R., Hoogen, R., Bramstedt, K., Eichmann, K.-U., Eisinger, M., and Perner, D.: The Global Ozone Monitoring Experiment (GOME): Mission Con- cept and First Scientific Results, J. Atmos. Sciences, 56, 151$175,1999$.

Danielsen, E. F: Stratosphere-Troposphere exchange based on radioactivity, ozone and potential vorticity, J. Atmos. Sci., 25, 502518, 1968.

Davies, T. and Schuepbach, E.: Episodes of high ozone concentrations at the surface resulting from transport down the upper troposphere/lower stratosphere: a review and case studies, Atmos. Environ., 28, 53-68, 1994.

De Muer, D., De Backer, H., and van Haven, P.: Analysis of 25 years of regular ozone soundings at Uccle Belgium, Atmospheric ozone as a Climate Gas (NATO ASI Series), edited by: Wang, W. C. and Isaksen, I. S. A., 113-130, 1995.

Ebel, A., Hass, H., Jakobs, H. J., Laube, M., Memmesheimer, M., Oberreuter, A., Geiss, H., and Kuo, Y. H.: Simulation of ozone intrusion caused by a tropopause fold and cut-off low, Atmos. Environ., 25A, 2131-2144, 1991.

Ebel, A., Elbern, H., Hendricks, J., and Meyer, R.: Stratospheretroposphere exchange and its impact on the structure of the lower stratosphere, J. Geom. Geol., 48, 135-144, 1995.

Eisele, H. and Trickl, T.: Lidar soundings of tropospheric ozone at Garmisch-Partenkirchen, Proc. 1996 Quadrennial Ozone Symposium, L'Aquila, Italy, International Ozone Commission, 351354, 1998.

Eisele, H., Scheel, H. E., Sladkovic, R., and Trickl, T.: Highresolution lidar measurements of stratosphere- troposphere exchange, J. Atmos. Sci., 56, 319-330, 1999.

Elbern, H., Kowol, J., Sladkovic, R., and Ebel, A.: Deep stratospheric intrusions: a statistical assessment with model guided analyses, Atmos. Environ., 31, 3207-3226, 1997.

Fishman, J. and Crutzen, P.: The origin of ozone in the troposphere, Nature, 274, 855-858, 1978.

Follows, M. J. and Austin, J.: A total average model of the stratospheric contributions to the tropospheric ozone budget, J. Geophys. Res., 97, 18 047-18 060, 1992.

Forster, C. and Wirth, V.: Radiative decay of stratospheric laminae in the troposphere, J. Geophys. Res., 105, 10 169-10 184, 1999.

Galani, E., Balis, D., Zanis, P., Zerefos, C., Papayannis, A., Wernli, H., and Gerasopoulos, E.: Observations of Stratosphere-toTroposphere Transport (STT) events over the Eastern Mediterranean using a ground-based lidar system, J. Geophys. Res., 108, 8527, doi:10.1029/2002JD002596, 2003.

Grabbe, G., Boesenberg, J., Dier, H., Goerdsorf, V., Matthias, V., Peters, G., Schaberl, T., and Senff, C.: Intercomparison of ozone measurements between lidar and ECC-sondes, Beitr. Phys. Atmosph., 189-203, 1996.

Gray, L., Bithell, M., and Cox, B.: The role of specific humidity fields in the diagnosis of stratospheric-tropospheric exchange, Geophys. Res. Lett., 21, 2103-2106, 1994.

Guirlet, M., Keckhut, P., Godin, S., and Mégie, G.: Description of the long-term ozone data series obtained from different instrumental techniques at a single location: the Observatoire de Haute Provence $\left(43.9^{\circ} \mathrm{N}, 5.7^{\circ} \mathrm{E}\right)$, Ann. Geophys., 18, 13251339, 2000,

SRef-ID: 1432-0576/ag/2000-18-1325.

Hoerling, M. P., Schaack, T. K., and Lenzen, A. J.: Global objective tropopause analysis, Month. Weather Rev., 119, 1816-1831, 1991.

Holton, J. R., Hayenes, P. H., McInyre, M. E., Douglass, R. A., Rood, R. B., and Pfister, L.: Stratosphere-Troposphere exchange, Rev. Geophysics, 33, 403-439, 1995.

Hoskins, B. J., McIntyre, M. E., and Robertson, A. W.: On the use 
and significance of isentropic potential vorticity maps, Quart. J. Roy. Met. Soc., 111, 877-945, 1985.

James, P., Stohl, A., Forster, C., Eckhardt, S., Seibert, P., and Frank, A.: A 15-year climatology of stratosphere-troposphere exchange with a Lagrangian particle dispersion model: 1. Methodology and validation, J. Geophys. Res., 108, 8519, doi:10.1029/2002JD002637, 2003.

Kayser, D. and Shapiro, M. A.: A review of the structure and dynamics of upper-level frontal zones, Month. Weather Rev., 114, 452-499, 1986.

Kempfer, U., Carnuth, W., Lotz, R., and Trickl, T.: A wide-range ultraviolet lidar system for tropospheric ozone measurements, Rev. Sci. Instrum., 65, 3145-3164, 1994.

Kentarchos, A. S., Davies, T. D., and Zerefos, C.: A low latitude stratospheric intrusion associated with a cut-off low, Geophys. Res. Lett., 25, 67-70, 1998.

Kentarchos, A. S., Roelofs, G. J., and Lelieveld, J.: Model study of a stratospheric intrusion event associated with the development of a cut-off low, J. Geophys. Res., 104, 1717-1727, 1999.

Kentarchos, A. S., Roelofs, G. J., and Lelieveld, J.: Simulation of extratropical synoptic-scale stratosphere-troposphere exchange using a coupled chemistry GCM: sensitivity to horizontal resolution, J. Atmos. Sci., 57, 2824-2838, 2000.

Komhyr, W. D.: Electrochemical Concentration Cells for gas analysis, Ann. Geophys., 25, 203-210, 1969.

Komhyr, W. D.: Operations Handbook-Ozone measurement to $40 \mathrm{~km}$ altitude with a 4A Electrochemical Concentration Cell (ECC) ozonesonde, NOAA Technical Memorandum, ERL ARL149, 50, 1986.

Komhyr, W. D., Barnes, R. A., Brothers, G. B., Lathrop, J. A., and Oppermann, D. P.: Electrochemical concentration cell performance evaluation during STOIC, J. Geophys. Res., 100, 92319244, 1995.

Kowol-Santen, J. and Ancellet, G.: Mesoscale analysis of transport across the subtropical tropopause, Geophys. Res. Lett., 27, 3345-3348, 2000.

Kourtidis, K., Balis, D., Galani, E., Ziomas, I., Papayannis, A., Perros, P., and Zerefos, C.: Regional tropospheric ozone over the Eastern Mediterranean Sea, J. Geophys. Res., 107(D12), 8140, doi:10.1029/2000JD000140, 2002.

Lazaridis, M., Spyridaki, A., Solberg, S., Smol'k, J., Zd'mal, V., Eleftheriadis, K., Aleksandropoulou, V., and Georgopoulos, P. G.: Mesoscale modeling of combined aerosol and photo-oxidant processes in the Eastern Mediterranean, Atmos. Chem. Phys., 5, 927-940, 2005,

\section{SRef-ID: 1680-7324/acp/2005-5-927.}

Logan, J. A.: Trends in the vertical distribution of ozone: an analysis of ozonesonde data, J. Geophys. Res., 99, 25 553-25 585, 1994.

Logan, J. A., Megretskaia, I. A., Miller, A. J., Tiao, G. C., Choi, D., Zhang, L., Stolarski, R. S., Labow, G. C., Hollandsworth, S. M., Bodeker, G. E., Claude, H., De Muer, D., Kerr, J. B., Tarasick, D. W., Oltmans, S. J., Johnson, B., Schmidlin, F., Staehelin, J., Viatte, P., and Uchino, O.: Trends in the vertical distribution of ozone: a comparison of two analyses of ozonesonde data, J. Geophys. Res., 104(D21), 26373-26399, 2001.

Oltmans, S. J., Lefohn, A. S., Scheel, H. E., Harris, J. M., Levy, H., Galbally, I. E., Brunke, E. G., Meyer, C. P., Lathrop, J. A., Johnson, B. J., Shadwick, D. S., Cuevas, E., Schmidlin, F. J., Tarasick, D. W., Claude, H., Kerr, J. B., Uchino, O., and Mohnen, V.: Trends of ozone on the troposphere, Geophys. Res. Lett., 25, 139-142, 1998.
Papayannis, A.: Etude expérimentale de la distribution verticale de l'ozone dans la troposphère par télédétection laser: Application aux echanges stratosphère-troposphère et a la physicochimie de la Couche Limite Atmospherique, Thèse de Doctorat de 3ème Cycle, Université Paris VII, Paris, 141, 1989.

Papayannis, A., Ancellet, G., Pelon, J., and Mégie, G.: Multiwavelength lidar for ozone measurements in the troposphere and the lower stratosphere, Appl. Opt., 29, 467-476, 1990.

Papayannis, A., Porteneuve, J., Balis, D., Zerefos, C., and Galani, E.: Design of a new DIAL system for tropospheric and lower stratospheric ozone monitoring in Northern Greece, Phys. Chem. Earth, 24, 439-442, 1999.

Pelon, J. and Mégie, G.: Ozone monitoring in the troposphere and the lower stratosphere: evaluation and operation of a groundbased lidar station, J. Geophys. Res., 87, 4947-4955, 1982.

Ravetta, F. and Ancellet, G.: Identification of dynamical processes at the tropopause during the decay of a cutoff low using highresolution airborne lidar ozone measurements, Mon. Wea. Rev., 128, 3252-3267, 2000.

Reed, R. J.: A study of characteristic type of upper level frontogenesis, J. Meteor., 12, 226-237, 1955.

Roelofs, G. J. and Lelieveld, J.: Model study of the influence of cross-tropopause ozone transports on tropospheric ozone levels, Tellus, 49, 38-55, 1997.

Roelofs, G. J., Lelieveld, J., and van Dorland, R.: A threedimensional chemistry/general circulation model simulation of anthropogenically derived ozone in the troposphere and its radiative climate forcing, J. Geophys. Res., 102, 23 389-23 401, 1997.

Shapiro, M. A.: Turbulent mixing within tropopause folds as a mechanism for the exchange of chemical constituents between the stratosphere and the troposphere, J. Atmos. Sci., 37, 9941004, 1980.

Stohl, A., Wotawa, G., Seibert, P., and Kromp-Kolb, H.: Interpolation errors in wind fields as a function of spatial and temporal resolution and their impact on different types of kinematic trajectories, J. Appl. Meteor., 34, 2149-2165, 1995.

Stohl, A. and Seibert, P.: Accuracy of trajectories as determined from the conservation of meteorological tracers, Q. J. R. Meteorol. Soc., 125, 1465-1484, 1998.

Stohl, A.: Accuracy and applications of trajectories - a review and bibliography, Atmos. Environ., 32, 947-966, 1998.

Stohl, A. and Trickl, T.: A textbook example of long-range transport: simultaneous observations of ozone maxima of stratospheric and N. American origin in the free troposphere over Europe, J. Geophys. Res., 104, 30 445-30 462, 1999.

Stohl, A., Spichtinger-Rakowsky, N., Bonasoni, P., Feldmann, H., Memmesheimer, M., Scheel, H. E., Trickl, T., Hubener, S., Ringer, W., Mandl, M.: The influence of stratospheric intrusions on alpine ozone concentrations, Atmos. Environ., 34, 13231354, 2000.

Stohl, A., Bonasoni, P., Christofanelli, P., Collins, B., Feichter, J., Frank, A., Forster, C., Gerasopoulos, E., Gaggeler, H., James, P., Kentarchos, T., Kreipl, S., Land, C., Meloen, J., Papayannis, A., Priller, A., Seibert, P., Sprenger, M., Roelofs, G., Scheel, E., Schnabel, C., Siegmund, P., Tobler, L., Trickl, T., Wernli, H., Wirth, V., Zanis, P., and Zerefos, C.: Stratosphere-Troposphere Exchange - A review and what we have learned from STACCATO, J. Geophys. Res., 108(D12), 8516, doi:10.1029/2002JD002490, 2003.

Trickl, T., Cooper, O., Eisele, H., James, P., Mücke, R., and Stohl, A.: Intercontinental transport and its influence on the ozone con- 
centrations over central Europe: Three case studies, J. Geophys. Res., 108(D12), 8530, doi:10.1029/2002JD002735, 2003.

Vaughan, G., Price, J. D., and Howells, A.: Transport into the troposphere in a tropopause fold, Q. R. J. Meteorol. Soc., 120, 10851103, 1994.

Vaughan, G., O'Connor, F. M., and Wareing, D. P.: Observations of streamers in the troposphere and stratosphere using ozone lidar, J. Atmos. Chem., 38, 295-315, 2001.

Wild, O., Pochanart, P., and Akimoto, H.: Trans-Eurasian transport of ozone and its precursors, J. Geophys. Res., 109, D11302, doi:10.1029/2003JD004501, 2004.

Wirth, V., Appenzeller, C., and Juckes, M.: Signatures of induced vertical air motion accompanying quasi-horizontal rollup of stratospheric intrusions, Month. Weather Rev., 125, 25042519, 1997.
World Meteorological Organization (WMO), Atmospheric Ozone 1985, vol. I., Rep. 16, Geneva, Switzerland, 478, 1986.

World Meteorological Organization (WMO), SPARC/IO ${ }_{3} \mathrm{C} / \mathrm{GAW}$ Assessment of trends in the vertical distribution of ozone, WMO Global Ozone Research and Monitoring Project, Rep. 43, Geneva, Switzerland, 295, 1998.

Zanis, P., Trickl, T., Stohl, A., Wernli, H., Cooper, O., Zerefos, C., Gäggler, H., Schnabel, C., Tobler, L., Kubik, P., Priller, A., Scheel, H., Kanter, H., Cristofanelli, P., Forster, C., James, P., Gerasopoulos, E., Dlecoo, A., Papayannis, A., and Claude, H.: Forecast, observation and modeling of a deep stratospheric intrusion event over Europe, Atmos. Chem. Phys., 3, 763-777, 2003. 